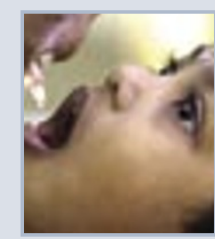

\author{
p1225 Drop down: \\ India is slipping \\ in its fight \\ against polio.
}

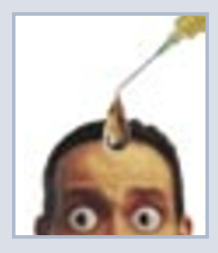
p1228 Private interests: Should governments mandate vaccinations?

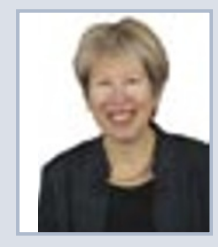

p1230 Springtime in Paris: Alice Dautry clears the air at the Institut Pasteur.

\title{
Troubling reports tarnish credibility of US drug agency
}

The US Food and Drug Administration, once a stalwart of global drug regulation, is flailing: reports of its problems hit the press nearly every day. And with no permanent leader at its helm, the agency's credibility is at an alarming low.

In a statement accompanying its September report, The Future of Drug Safety, the esteemed Institute of Medicine (IOM) declared that the 100-year-old agency's safety efforts are plagued by a "lack of clear regulatory authority, chronic underfunding, organizational problems, and a scarcity of post-approval data about drugs' risks and benefits."

As a result, "there is a perception of crisis that has compromised the credibility of FDA and the pharmaceutical industry," the report said.

"We see an erosion of public trust and an erosion of morale by the FDA staff," says David Graham, the FDA epidemiologist whose searing Senate testimony in 2004 on Vioxx vaulted the agency into the Congressional spotlight. "There are several areas where, globally, FDA is in need of radical, revolutionary change," he says.

Graham does not speak for the agency, and a senior FDA official could not be reached to comment for this article.

IOM's list of prescriptions for the ailing

\section{Proportion of US Food and Drug Administration scientists who say:}

Have been asked to provide incomplete, inaccurate or misleading information to the public, media or government officials

Have been asked to inappropriately exclude or alter information or conclusions in an FDA scientific document

FDA political appointees have inappropriately injected themselves into FDA determinations or actions

The public would be better served if the independence and authority of FDA postmarket safety systems were strengthened

FDA has enough resources to protect public health and relay accurate sciencebased information

*Based on survey responses of 997 scientists at the FDA.

Sinking morale: Employees say the FDA needs radical change. $61 \%$
$\$ 1.9$ billion agency include a big boost in congressional funding and the power to compel drugmakers to change labels or conduct safety studies on approved drugs. The IOM also recommends mandatory labeling of new drugs, perhaps with a black triangle, to warn consumers that their risks haven't yet been fully explored.

The report is just one in a litany of problems plaguing the FDA, beginning with the fact that the agency has been leaderless for more than four of the last six years.

The last commissioner, Lester Crawford, lasted just two months and is facing criminal charges for lying about his financial conflicts of interest. Mark McClellan, Crawford's capable predecessor, decamped from his post after 17 months.

To boost stability, the IOM recommends that FDA commissioners serve a fixed six-year term. But the current nominee, former National Cancer Institute director Andrew von Eschenbach, is stalled by political wrangling in the Senate.

Of equal concern to many in the agency is perceived political meddling in its decisions. In an anonymous survey of roughly 1,000 agency scientists published in July by the leftleaning advocacy group Union of Concerned Scientists, $61 \%$ said they knew of cases where political appointees had inappropriately injected themselves into FDA decision making. And 18\% said they had been asked to inappropriately exclude or change data or their own conclusions.

Not surprisingly, attrition rates among FDA scientists are roughly twice those at comparable agencies, according to a 2002 Government Accountability Office report.

The unending list of troubles is $81 \%$ $25 \%$ taking its toll on the image of the agency. A Harris poll released in May showed that $36 \%$ of people think the FDA does a good or excellent job of ensuring drug safety, down from 56\% in 2004.

The pharmaceutical industry agrees with one conclusion of the IOM report: that the system to monitor the safety of approved drugs needs serious improvement.
"The big issue is the development of new tools for pharmacovigilance - and that's something that both we and the FDA are actively pursuing," says Alan Goldhammer, associate vice-president for regulatory affairs at the Pharmaceutical Research and Manufacturers of America, the industry's Washington-based lobbying group.

On other issues the IOM report overstated matters, Goldhammer says. "To say that things are totally broken is incorrect," he says. "Looking historically we are not seeing any greater number of drug withdrawals than the historical norm."

Also running against the trend of gloomy reports, the non-profit National Bureau of Economic Research (NBER) last year released a different assessment of the FDA's efforts to ensure that prescription drugs are safe and effective.

NBER considered 662 drugs approved between 1979 and 2002 in an effort to gauge the impact of the Prescription Drug User Fee Act. Under the 1992 law, companies began paying the agency hundreds of millions of dollars in exchange for speedier reviews of their applications. Critics charge that the law has undermined the FDA's independence by making it beholden to the industry it's supposed to regulate.

The NBER report, however, reached a different conclusion, saying that by speeding up drug approval, the law saved between 180,000 and 310,000 life-years between 1992 and 2002.

Still, FDA critics insist on one thing: that Congress should endow the agency with more money and legal muscle to enforce safety standards. September 2007, when the 1992 law must be reauthorized by Congress, presents a rare opportunity to make this happen.

"In the wake of the Vioxx fiasco, we probably have greater impetus for reform at the FDA today than at any time since 1962," says Merrill Goozner of the Washington-based Center for Science in the Public Interest.

It was in 1962 that Congress first gave the FDA the power to demand that drugmakers conduct safety and efficacy tests. The impetus: the birth of thousands of babies with flipper-like stumps where their arms should have been after their pregnant mothers took an anti-nausea drug called thalidomide.

Meredith Wadman, Washington DC 